\title{
Organic matter composition in the sediment of three Brazilian coastal lagoons - District of Macaé, Rio de Janeiro (Brazil)
}

\author{
KLAUS-GERHARD ZINK ${ }^{1}$, ANDRÉ L.S. FURTADO ${ }^{2}$, PETER CASPER ${ }^{3}$ \\ and LORENZ SCHWARK ${ }^{1}$ \\ ${ }^{1}$ Geological Institute, University of Cologne, Zülpicher Str.49a, 50674 Cologne, Germany \\ ${ }^{2}$ Departamento de Ecologia, Instituto de Biologia, Universidade Federal do Rio de Janeiro \\ Cidade Universitária, Ilha do Fundão, 21591-590 Rio de Janeiro, Brasil \\ ${ }^{3}$ Leibniz-Institute of Freshwater Ecology, Department of Limnology of Stratified Lakes, \\ Alte Fischerhütte 2, 16775 Stechlin-OT Neuglobsow, Germany
}

Manuscript received on April 10, 2003; accepted for publication on October 1, 2003; presented by KenITIRo SUGUIO

\begin{abstract}
Freshwater lagoons comprise important coastal ecosystems and natural buffers between urbanized land areas and open ocean in the Rio de Janeiro State, Brazil. Studies of sediment and water chemistry, zooplankton and bacterial communities to assess the extent of anthropogenic disturbance are available. Here we contribute with an organic-geochemical approach supplemented by some microbiological aspects to complete the characterization of these lagoonal ecosystems. Bulk organic matter and extractable lipids (aliphatic hydrocarbons, alcohols and fatty acids, sterols) were investigated from two locations per lagoon: at the seaward site and landward ends - and at two depth intervals $(0-3$ and $3-6 \mathrm{~cm})$ per site. Urbanized Imboacica Lagoon received increased anthropogenic input over the most recent years represented by the topmost $3 \mathrm{~cm}$ of sediment, whereas deeper sediment layers are less affected by human influence. Eutrophication or nutrient availability favored enhanced algal/cyanobacterial growth. In remote Cabiúnas and Comprida Lagoons pristine conditions are preserved. Organic matter from vascular plants dominates (chain length of free lipids up to C36), which is exceptionally well preserved by acidic lagoonal waters. Differentiation between landward and seaward sites in these two lagoons is less well established due to much smaller surface/volume to catchment ratios. No anthropogenic influences are yet detectable in sediments of Cabiúnas and Comprida Lagoons.
\end{abstract}

Key words: coastal lagoons, aqueous/terrigenous bioproduction, lipids, fatty acids, sterols, Brazil.

\section{INTRODUCTION}

In the densely populated Rio de Janeiro State (Brazil), freshwater lagoons comprise important coastal ecosystems, often forming natural buffer regions between urbanized land areas and the open

Correspondence to: Lorenz Schwark

E-mail: lorenz.schwark@uni-koeln.de

E-mails: zink@gfz-postdam.de / pc@igb-berlin.de ocean. These lagoons are highly sensitive to anthropogenic influences due to heavy utilization for fishing, recreational activities and discharge of urban sewage. Several studies have shown the extent of anthropogenic disturbance in these natural ecosystems by means of investigating sediment and water chemistry (Furtado et al. 1997, Santos et al. 1998), as well as monitoring zooplankton (Kozlowski-Suzuki 
et al. 1998) and bacterial communities (Furtado and Esteves 1997, Biesboer et al. 1998). In addition studies in the Patos Lagoon (Brazil), the largest in South America, have demonstrated chemical processes concerning nutrients and trace metals on a larger scale but in a comparable environmental setting (Windom et al. 1999).

Organic material from autochthonous and allochthonous origin accumulates in the sediment of aquatic ecosystems. Here it supports bacterial activity that results in decomposition and nutrient recycling. By mediating $\mathrm{Eh}$ and $\mathrm{pH}$, microorganisms also influence physicochemical properties of the water column and sediment pore water. For a complete characterization of lagoonal ecosystems, an approach using organic-geochemical techniques combined with microbiological data and general limnological studies is especially informative.

In this investigation sediments from three coastal lagoons in the district of Macaé, State of Rio de Janeiro, Brazil, each experiencing different degrees of exposure to anthropogenic pollution, were studied by organic-geochemical techniques. Bulk organic matter and extractable lipids were investigated from two locations per lagoon.

Biological sources for organic matter deposited in the sediment, i.e. terrigenous, aquatic, macrophytic, soil-derived or of bacterial origin were identified. In order to discern changes in organic matter composition that occurred over the last decades and also to account for naturally occurring diagenetic processes, two depth intervals ( $0-3$ and 3-6 cm) were sampled at each site. Organic-geochemical results obtained from sediment samples are discussed and interpreted along with available ecological data.

\section{MATERIALS AND METHODS}

\section{StUdy AREA}

The lagoons are situated in the coastal area of the Macaé region, Brazil (22 $30^{\circ} \mathrm{S}$ and $\left.44^{\circ} 42^{\prime} \mathrm{W}\right)$ (Fig. 1) and were formed during the last Holocene transgression period (Perrin 1984). The regional climate is warm and humid; temperatures range from $18.7^{\circ} \mathrm{C}$ to $27.4^{\circ} \mathrm{C}$ with lowest precipitation in winter $(43.8 \mathrm{~mm})$ and highest in summer $(185.8 \mathrm{~mm})$ (FIDERJ 1977).

The lagoons are completely separated from the ocean by sand bars about $100 \mathrm{~m}$ in width. Imboacica Lagoon has a length of $5.3 \mathrm{~km}$, the length of the two other lagoons approximate $1 \mathrm{~km}$, max. depths are 2 m (Imboacica Lagoon), 4 m (Cabiúnas Lagoon), and $2.5 \mathrm{~m}$ (Comprida Lagoon). Water temperatures of the three lagoons vary around $20^{\circ} \mathrm{C}$ minimum and $29^{\circ} \mathrm{C}$ maximum and the values of $\mathrm{pH}$, and salinity decrease from Imboacica Lagoon $(\mathrm{pH} 8.3$; salinity maximum $17.9 \%$ ) to Comprida Lagoon ( $\mathrm{pH} 5$; salinity maximum $5 \%$ ) (Table I), reflecting the influence of marine water. Oxygen concentrations show comparable trends. Salinity in the Cabiúnas and Comprida Lagoons varies due to seawater sprays, high tide events, and artificial opening of the sand bar.

The Cabiúnas and Comprida Lagoons show a typical freshwater fauna (Kozlowsky-Suzuki et al. 1998). Mainly in Comprida Lagoon the water is colored by humic substances, resulting in lower values of transparency (Table I). These two lagoons situated in the National Park Restinga de Jurubatiba are surrounded by a typical dense sand dune vegetation (called Restinga) mainly represented by Theopharastaceae, Anarcadiaceae, Myrtaceae, Clusiaceae, Ericaceae, Melastomataceae, and Bignoniaceae (Araújo and Henriques 1984).

All three water bodies are polymictic through the whole year with the littoral zone colonized by macrophytes like Typha domingensis, Elecocharis fistulosa, Potamogeton stenostachys, Nymphaea ampla, Salvinia sp., and Utricularia sp., and the macroalga Chara, showing high abundance in the pelagic zone of Imboacica Lagoon.

Eutrophic Imboacica Lagoon is situated in the urban area of Macaé. From 1969 to 1994 about $7.3 \%$ of the littoral zone was settled by farms and residences (Santos et al. 1998) that released their agricultural and domestic waste into Imboacica Lagoon. The daily input of nitrogen and phosphorus is about $70 \mathrm{~kg}$ and $7 \mathrm{~kg}$ respectively (Lopez-Ferreira 


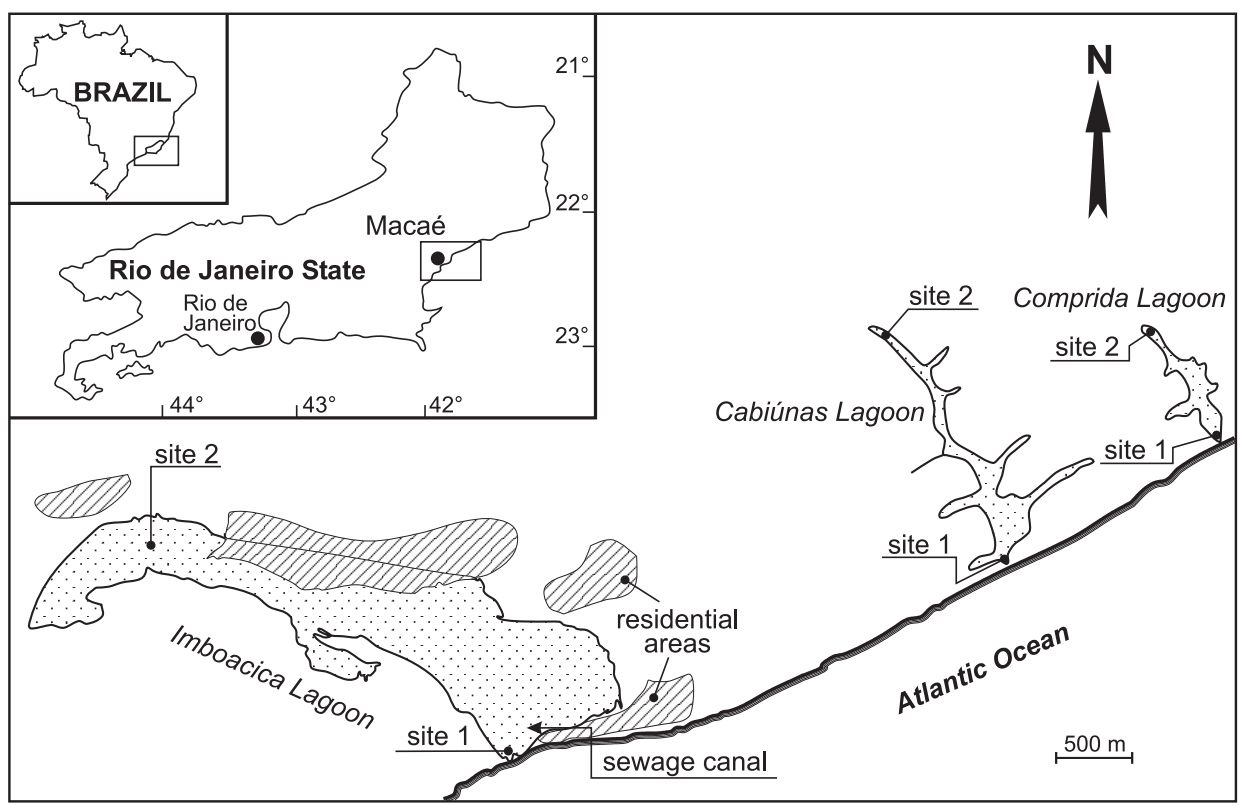

Fig. 1 - Location of study area and indication of sampling sites in three investigated coastal lagoons.

\section{TABLE I}

Selected morphological and limnological parameters of Imboacica,

Cabiúnas and Comprida Lagoons.

\begin{tabular}{|c|c|c|c|c|}
\hline Lagoon & & Imboacica & Cabiúnas & Comprida \\
\hline Area $\left(\mathrm{km}^{2}\right)^{1}$ & & 3.26 & 0.34 & 0.13 \\
\hline \multirow[t]{2}{*}{ Depth $(\mathrm{m})^{1}$} & mean & 1.1 & 2.4 & 1.6 \\
\hline & $\max$ & 2.0 & 4.0 & 2.5 \\
\hline Length $(\mathrm{km})^{1}$ & $\max$. & 5.3 & 0.9 & 1.0 \\
\hline Width $(\mathrm{km})^{1}$ & $\max$. & 1.3 & 0.2 & 0.5 \\
\hline \multirow[t]{2}{*}{ Water temperature $\left({ }^{\circ} \mathrm{C}\right)^{2}$} & $\min$. & 18.9 & 21.0 & 22.0 \\
\hline & $\max$. & 29.9 & 28.5 & 28.9 \\
\hline \multirow[t]{2}{*}{ Secchi depth $(m)^{2}$} & $\min$. & 0.7 & 0.8 & 0.3 \\
\hline & $\max$ & 1.7 & 2.8 & 0.7 \\
\hline \multirow[t]{2}{*}{$\mathrm{pH}^{2}$} & $\min$. & 7.2 & 6.0 & 3.9 \\
\hline & $\max$. & 9.4 & 7.4 & 6.1 \\
\hline \multirow[t]{2}{*}{ Conductivity $\left(\mathrm{mS} \mathrm{cm}^{-1}\right)^{2}$} & $\min$. & 2.2 & 0.3 & 0.1 \\
\hline & $\max$. & 16.1 & 14.3 & 9.6 \\
\hline \multirow[t]{2}{*}{ Salinity $(\% \circ)^{2}$} & $\min$. & 0 & 0 & 0 \\
\hline & $\max$. & 17.9 & 12.0 & 5.0 \\
\hline \multirow[t]{2}{*}{${\text { Oxygen }(\% \text { saturation })^{2}}^{2}$} & $\min$. & 58.6 & 24.0 & 43.7 \\
\hline & $\max$. & 163.0 & 116.0 & 99.0 \\
\hline
\end{tabular}

${ }^{1}$ According to Panosso et al. (1998). ${ }^{2}$ According to Petrucio (1998). Data from May 1993 to November 1995. 
1998). Another anthropogenic impact is the artificial opening of the sand bar, causing the drainage of the lagoon to the ocean (last opening for Imboacica and Cabiúnas Lagoons occurred in February 1998). After the drainage the water level is very low and large areas of the lagoon sediment are uncovered.

\section{SAMPLING AND ANALYSIS}

Sampling was carried out in September 1998 using a core sampler as described in Ambül and Bührer (1975). At each location sediment cores were taken at the most seaward end (site 1: close to the sandbar separating lagoon and ocean) and at the most landward position (site 2: macrophytic littoral) of each lagoon and sliced each in $0-3 \mathrm{~cm}$ and $3-6 \mathrm{~cm}$ subsamples. At both positions selected sediments are representative for the two contrasting sedimentation regimes within the lagoons. Accumulation rates for sediment could not be calculated because absolute age determination via e.g. ${ }^{210} \mathrm{~Pb}$-dating was not available.

Sediments from site 1 consist of coarse sand and gravel, and sediments from site 2 are sandy to silty and organic rich with frequent coarse plant detritus. After removal of coarse pebble (diameter $>10 \mathrm{~mm}$ ) and plant debris, 12 samples were oven-dried at $45^{\circ} \mathrm{C}$. Following homogenization, elemental analysis was carried out on a LECO CS225 with determination of total carbon (TC), total sulfur (TS) and, after acidic removal of carbonates, of total organic carbon (TOC) by combustion and IRdetection of evolved gases. Total inorganic carbon (TIC) was calculated by difference between TC and TOC and calcite carbonate concentrations obtained by multiplication of TIC with a stochiometry factor of 8.33. Total nitrogen (TN) values were determined on a HERAEUS elemental analyzer on decarbonated sediment (Table II). Due to low concentrations of organic matter total nitrogen was below detection limit in all seaward sites.

Due to the heterogeneity and limited amounts of sediment material the extent of analytical processing had to be restricted, and the initial weight of sediment for extraction varied depending on the different densities (Table III). Dried samples were extracted with dichloromethane (DCM) using ASE (Accelerated Solvent Extraction) at $75^{\circ} \mathrm{C}$ and 50 bar for $20 \mathrm{~min}$ to obtain the complete free lipid fraction including polar compounds. This approach is comparable to methods applied to modern sediments by Hinrichs et al. (2000), Lutz et al. (2000), Budge and Parrish (1998), and Ficken et al. (2000). Excess solvent was removed by evaporation under reduced pressure and the organic extract was again taken up in small amounts of DCM. BSTFA was added to silylate alcohols and convert carboxylic acids to corresponding esters prior to gas chromatography.

Gas chromatography was performed on a HP 5890 instrument equipped with a HP5 column (length $30 \mathrm{~m}, 0.25 \mathrm{~mm}$ ID, $0.25 \mu \mathrm{m}$ film thickness) coated with 5\% phenylsiloxane. Helium was used as carrier gas with a constant flow of $1.5 \mathrm{ml} / \mathrm{min}$. Injection was done at $40^{\circ} \mathrm{C}$ in on-column mode and signals recorded by flame ionization detection. Oven temperature was programmed from $40^{\circ} \mathrm{C}$ to $140^{\circ} \mathrm{C}$ at $8.5^{\circ} \mathrm{C} / \mathrm{min}$, followed by at $3.5^{\circ} \mathrm{C} / \mathrm{min}$ to $320^{\circ} \mathrm{C}$ and kept isothermal for $60 \mathrm{~min}$. Compound identification was achieved by adding external standards and comparing retention times with standard mixtures. Elution order of mono-unsaturated fatty acids was determined by comparison with literature data (e.g. Volkman et al. 1989). Four samples were analyzed by gas chromatography/mass spectrometry using a Single Quadrupole instrument (HP 5890/5889MS Engine). EI-mass spectra were acquired at $70 \mathrm{eV}$ in full scan mode recording from 50 to $650 \mathrm{amu}$. GC conditions were identical to the ones used for GC-FID.

\section{RESULTS AND DISCUSSION}

\section{Elemental Analyses}

In all three lagoons samples from the area near the sand bar (site 1: seaward site) have a total carbon content (TC) of less than $1 \%$ of dry weight (dw) and a sulfur content of $<0.1 \%$ of dw, i.e. close to the detection limit (Table II). This low abundance of organic matter is in accordance with the coarse 
TABLE II

Elemental analysis data and organic carbon/nitrogen ratio in sediment samples from Imboacica, Cabiúnas and Comprida Lagoons (1: seaward site; 2: landward site).

\begin{tabular}{l|c|c|c|c|c|c|c}
\hline Lagoon & $\begin{array}{c}\text { Depth } \\
\text { interval [cm] }\end{array}$ & TC[\%] & TOC[\%] & TIC[\%] & TS[\%] & TN[\%] & $\begin{array}{c}\text { TOC/N } \\
\text { [molar ratio] }\end{array}$ \\
\cline { 3 - 8 } & & average & average & average & average \\
$\mathrm{n}=3$ & $\mathrm{n}=3$ & $\mathrm{n}=3$ & average & $\begin{array}{c}\text { average } \\
\mathrm{n}=2\end{array}$ \\
\hline Imboacica 1 & $0-3$ & 0.29 & n.d. & n.d. & $<0.05$ & n.d. & n.d. \\
seaward & $3-6$ & 0.46 & n.d. & n.d. & $<0.05$ & n.d. & n.d. \\
\hline Imboacica 2 & $0-3$ & 6.98 & 5.93 & 1.05 & 0.4 & 0.43 & 16.09 \\
landward & $3-6$ & 5.44 & 5.41 & 0.03 & 0.31 & 0.36 & 17.53 \\
\hline Cabiúnas 1 & $0-3$ & 0.05 & n.d. & n.d. & $<0.05$ & n.d. & n.d. \\
seaward & $3-6$ & 0.06 & n.d. & n.d. & $<0.05$ & n.d. & n.d. \\
\hline Cabiúnas 2 & $0-3$ & 0.70 & 0.50 & 0.20 & $<0.05$ & n.d. & n.d. \\
landward & $3-6$ & 1.25 & 1.25 & 0 & 0.06 & 0.07 & 20.83 \\
\hline Comprida 1 & $0-3$ & 0.11 & n.d. & n.d. & $<0.05$ & n.d. & n.d. \\
seaward & $3-6$ & 0.11 & n.d. & n.d. & $<0.05$ & n.d. & n.d. \\
\hline Comprida 2 & $0-3$ & 21.5 & 21.98 & 0 & 0.34 & 1.28 & 20.03 \\
landward & $3-6$ & 34.1 & 34.88 & 0 & 0.48 & 2.13 & 19.11 \\
\hline
\end{tabular}

\section{TABLE III}

Biomarkers detected in all studied samples (1: seaward site; 2: landward site).

\begin{tabular}{|c|c|c|c|c|c|c|c|c|}
\hline Lagoon & $\begin{array}{c}\text { Depth } \\
\text { interval } \\
{[\mathrm{cm}]}\end{array}$ & $\begin{array}{c}\text { Initial weight } \\
\text { for extraction } \\
{[\mathrm{g}]}\end{array}$ & $\begin{array}{c}\text { Extraction } \\
\text { yield } \\
{[\mathrm{ppm}]}\end{array}$ & $\begin{array}{c}\text { Extraction } \\
\text { yield } \\
\text { [mgExt/ } \\
\text { gTC] }\end{array}$ & $\begin{array}{c}\text { TAR: even } \\
\text { FA } \\
{[24-34] /} \\
{[14-18]}\end{array}$ & $\begin{array}{c}\text { FA } \\
{[18: 1 \omega 7 /} \\
18: 0]\end{array}$ & $\begin{array}{c}\text { FA } \\
{[16: 1 \omega 7 /} \\
16: 0]\end{array}$ & $\begin{array}{c}n \text {-alkane } \\
\text { ratio } \\
27 / \\
{[27+29+31]}\end{array}$ \\
\hline Imboacica 1 & $0-3$ & 50.5 & 13 & 4.4 & 0.001 & 0.8 & 0.73 & n.d \\
\hline seaward & $3-6$ & 45.7 & 11 & 2.4 & 0.28 & 0.74 & 0.70 & n.d \\
\hline Imboacica 2 & $0-3$ & 16.4 & 5526 & 80 & 27.2 & 0.46 & 0.34 & 26.7 \\
\hline landward & $3-6$ & 11.2 & 5815 & 107 & 50.2 & 0.41 & 0.23 & n.d \\
\hline Cabiúnas 1 & $0-3$ & 49.4 & 8 & 16 & 0.27 & 0.58 & 0.44 & n.d \\
\hline seaward & $3-6$ & 49.1 & 10 & 17 & 0.23 & 0.71 & 0.53 & n.d \\
\hline Cabiúnas 2 & $0-3$ & 43.4 & 113 & 16 & 6.87 & 0.45 & 0.20 & 14.5 \\
\hline landward & $3-6$ & 46.8 & 226 & 18 & 5.72 & 0.32 & 0.24 & n.d \\
\hline Comprida 1 & $0-3$ & 47.0 & 15 & 13 & 1.38 & 0.43 & 0.44 & n.d \\
\hline seaward & $3-6$ & 51.3 & 14 & 13 & 2.85 & 0.36 & 0.37 & n.d \\
\hline Comprida 2 & $0-3$ & 7.6 & 12440 & 58 & 9.05 & 0.84 & 0.31 & 14.8 \\
\hline landward & $3-6$ & 3.8 & 21719 & 64 & 7.04 & 1.20 & 0.44 & n.d \\
\hline
\end{tabular}

grain lithology of these samples. Samples from the macrophytic littoral (site 2: landward site) of each lagoon possess TC contents between 0.7 and $34.1 \%$. Total organic carbon content (TOC) could only be determined for samples with $>1 \%$ TC (Table II) due to restriction in sample amount. Only the surface sediment layer of the landward site at Imboacica Lagoon contained carbonate carbon - the calculated inorganic carbon content (TIC) shows a value of $1.05 \%$ corresponding to app. $9 \%$ calcium carbon- 
ate by weight. The remaining samples are virtually carbonate-free as indicated by lack of $\mathrm{CO}_{2}$ generation upon decarbonatization. The TC-values measured in triplicate were therefore taken as more accurately reflecting total organic matter abundance and used for normalization of extraction yields. The low abundance of carbonate is in accordance with the freshwater character of the lagoons and the higher acidic environment reported for Cabiúnas and Comprida Lagoons (Petrucio 1998). Enhanced alkalinity and pH-values (7.2-9.4) in Imboacica Lagoon during May 1993 to November 1995 (Table I) may account for the increased TIC-content noted exclusively for the uppermost sample and thus indicate anthropogenic influences.

TOC-values of the landward site at Comprida Lagoon are slightly higher than corresponding TCvalues (Table II). The deviation however lies within the analytical error of the LECO elemental analyzer and may also be attributed to sample inhomogeneity. TC-concentrations exhibit significant differences between the lagoons (Fig. 2). Samples from Comprida Lagoon at the landward site, which is covered with dense macrophyte vegetation, show very high TC-values $(0-3 \mathrm{~cm}=21.5 \%$ and $3-6 \mathrm{~cm}=$ $34.1 \%$ ) and TOC-values identical within analytical error limits, i.e. the sediments are carbonate-free. Even so the general trend of high organic carbon content is not affected by the discrepancy between TC and TOC. Increase of TC- and TOC-values with depth is typical for the undisturbed lagoons (Comprida and Cabiúnas) and can be explained by a better preservation with increasing sediment depth induced by stronger reducing conditions or by intensified dilution of superficial sediments by soil derived detritus. The lowest TOC-values at the landward site of Cabiúnas Lagoon reflected the lower macrophyte density. At this area the sediment is composed basically of sandy particles (Gonçalves et al. 1998).

In contrast, Imboacica Lagoon shows an increase of TC for the surficial layer of sediment (Table II), accompanied by a slight increase in TOC-values. As already noted for TIC, this can be attributed to anthropogenic eutrophication in Imboacica Lagoon.
In Comprida Lagoon sources for enrichment of organic matter are authochthonous (primary producers such as phytoplankton and macrophytes) and allochthonous (surrounding vegetation of Restinga). Comprida Lagoon shows the lowest $\mathrm{pH}$ and oxygen saturation (Table I) and water is colored dark by humic substances, which may inhibit microbial decomposition of accumulated organic matter (Qualls and Haines 1990). Imboacica and Comprida Lagoons show higher TC-values and sulfur contents in excess of $0.1 \%$. (Table II) at the landward site only. Sulfur concentrations of 0.31 to $0.48 \%$ in organic matter rich depositional setting are particularly low, even for freshwater environments known to be sulfate depleted. This might indicate low activity of sulfate reducing bacteria and either a limitation of iron or sulfate in the pore water. Consequently a low potential for pyrite fixation prevailed in the lagoonal sediments.

Total nitrogen content determined for the five organic rich samples from landward sites in the three lagoons range between 0.07 to $2.13 \%$. A positive correlation between total nitrogen and TOC is observed with $\mathrm{C} / \mathrm{N}$-ratios varying between 16.1 to 20.8 (Table II). This clearly indicates a significant contribution of $\mathrm{N}$-depleted terrigenous organic matter, although strong microbial activity will affect $\mathrm{N}$-cycling in the lagoonal sediments (Meyers and Ishiwatari 1993, Tyson 1995). Pedrosa et al. (1999) described an obvious dominance of the $\mathrm{N}_{2}$-fixing cyanobacteria Cylindrospermopsis raciborskii in $\mathrm{N}$ depleted Cima Lake, Brazil. In Imboacica Lagoon blooms of cyanobacteria dominated by few species - e.g. Cylindrospermopsis raciborskii - and one bacillariophycea (diatom) were observed periodically in summer when the water level decreases and sewage concentrates in the lagoon. Nitrogen fixation by these diazotrophic cyanobacteria might increase the N-content of the sediment. Enhanced nitrogen availability due to sewage input potentially triggered diatom blooms and subsequently nitrogenrich algal biomass was deposited. A comparable ecological effect could not be observed for the two other Macaé lagoons. The lower $\mathrm{C} / \mathrm{N}$-ratio in upper 


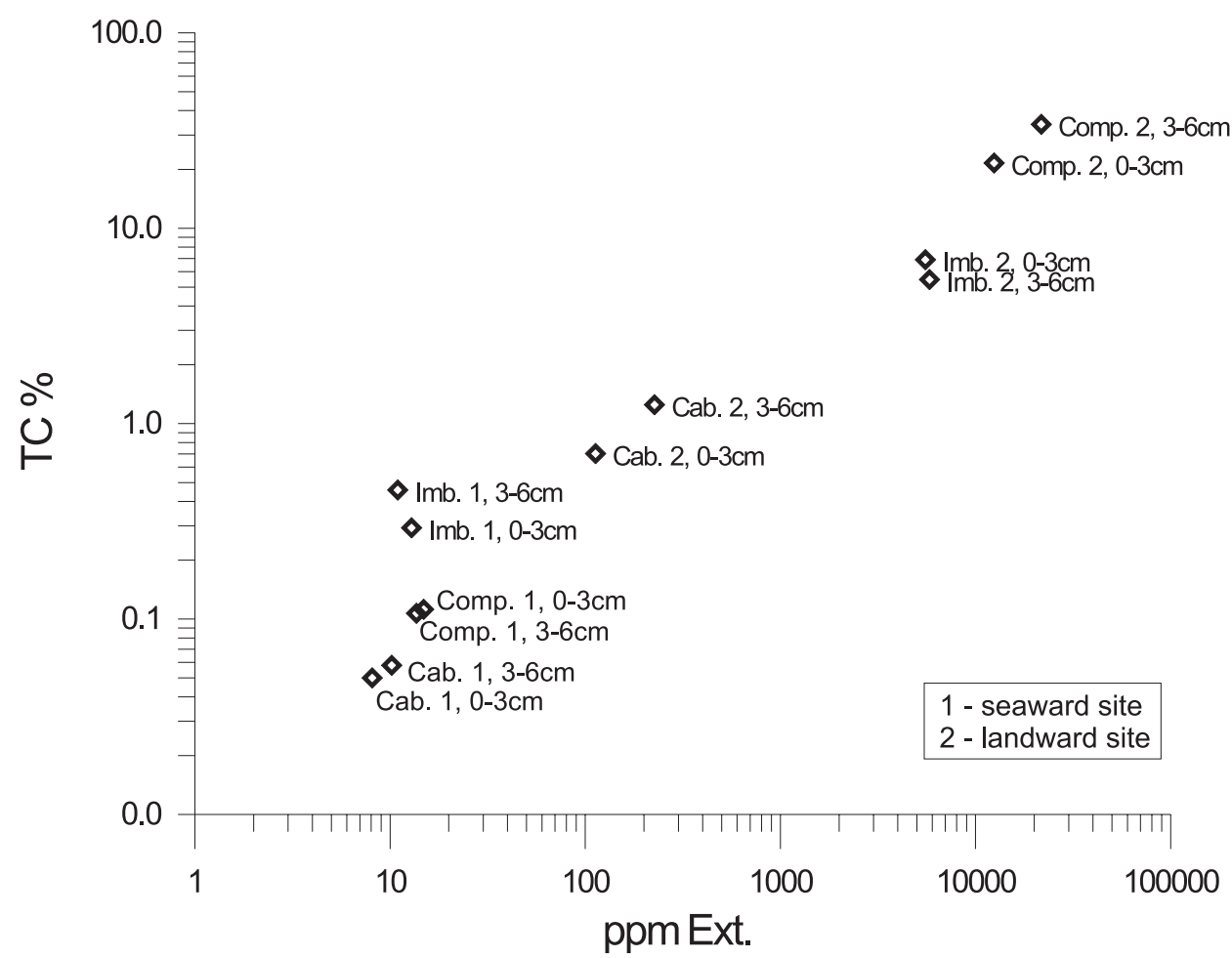

Fig. 2 - Crossplot of total carbon (\% dw) versus dichloromethane-extractable organic matter (ppm).

and partly the lower Imboacica Lagoon landward site sediments (Table II) is thus a combined effect of higher macrophyte productivity, nitrogen fixing cyanobacteria and sewage induced diatom blooms. All of these processes are related to anthropogenically-induced eutrophication.

\section{LIPID CONCENTRATION}

Organic solvent yields of lipid extraction and TCnormalized extraction yield (mgExt/gTC) are very low for the seaward site, contrasting with the high values found at the landward site from Imboacica and Comprida Lagoons (Table III). As observed for $\mathrm{TC}$, the lowest values of ppm Ext were measured at the seaward site of Cabiúnas Lagoon, reflecting the sediment coarseness and the lower macrophyte density. A relation between lipid yields and TCor TOC-values is noted for all samples (Fig. 2) and extraction yields of the landward site from all three lagoons increase with depth from $0-3$ to $3-$ $6 \mathrm{~cm}$. Increasing TC-normalized extraction yields with depth indicate enhanced early diagenetic transformation of polymeric biolipids into free organic lipids in the sediment (Table III). Extraction yields normalized to TC for Imboacica Lagoon at the landward site are higher than for Comprida Lagoon (Table III). This points towards a higher relative proportion of autochthonous algal organic material in Imboacica Lagoon than in Comprida Lagoon. TCnormalized extraction yields for Cabiúnas Lagoon at the landward site exhibit low ratios that do not differ from seaward site values. This either indicates strong in situ degradation of sedimented organic matter in the macrophyte littoral region, if oxidizing conditions prevail, or accumulation of predominantly refractory terrigenous organic matter at this site.

Bulk results confirm the contrast in depositional setting between the seaward and landward parts of the lagoons. In the latter organic matter accumulation prevails in the vicinity of littoral macrophyte growth areas. In seaward sites planktonic 
algal biomass accumulation predominates. More brackish and eutrophic conditions with intensified algal and bacterial productivity and biomass accumulation were noted only in the uppermost $3 \mathrm{~cm}$ of Imboacica Lagoon.

\section{LIPID COMPOSITION}

\section{Molecular composition of lipids \\ from the seaward sites}

Free lipid extracts of these samples are clearly dominated by short-chain saturated and unsaturated nC14-nC18-carboxylic acids (Fig. 3a-c), mainly produced by planktonic algae and/or cyanobacteria (Han and Calvin 1969, Gelpi et al. 1970, Volkman 1986, Volkman et al. 1989). A minor contribution of short-chain fatty acids will also always result from vascular plants. Especially the extract of the surface sediment $(0-3 \mathrm{~cm})$ of Imboacica Lagoon shows an extremely high abundance of n-C16:1 $\omega 7$ and n-C16:0 fatty acids (Fig. 3a) accompanied by abundant n-C14:0 fatty acid. Higher proportions of n-C16:1 $\omega 7$ are known from diatoms but can also be enhanced in cyanobacteria (e.g. Volkman et al. 1998, Wakeham 1995, Napolitano 1998). Conversely, a low diversity of isoprenoidal and longchain components occurs. This composition might be caused by mass blooms of cyanobacteria and diatoms with high tolerance towards drastically changing water chemistry in Imboacica Lagoon (very low water level, increase of sewage concentration). These changes are a consequence of sewage-induced eutrophication (note vicinity of sewage discharge channel to the seaward site shown in Fig. 1). Alternatively, the artificial opening of the sand bar to stimulate water exchange between lagoon and open ocean might stimulate ingression and growth of brackish algae species. The n-C16:1 $\omega 9$ unsaturated fatty acid almost exclusively reported for heterotrophic marine bacteria (Bertone et al. 1996) was only detected in Cabiúnas Lagoon, although in minor abundance. In this small and ecologically pristine lagoon the lipid distribution is not preferentially controlled by algal/bacterial mass blooms, usually leading to a dominance of the $\mathrm{n}-\mathrm{C} 16: 1 \omega 7$ isomer. A more marine influenced microbial composition in this particular lagoon is favored by artificial opening of the lagoon towards the open ocean.

Water temperature affects the ratio of diunsaturated vs. mono-unsaturated short-chain fatty acids (Kawamura and Ishiwatari 1981), but this factor does not play an important role in Macaé coastal lagoons. In Cabiúnas Lagoon seasonal variation of water temperature is low - even in winter water is about $20^{\circ} \mathrm{C}$ (Furtado et al. 2001). Diunsaturated acids were only detected as trace amounts in landward sites, 0-3 cm, of Comprida and Cabiúnas Lagoons. The proportion of monounsaturated (n-C16:1 $\omega 7$ ) to saturated n-C16-fatty acids consequently indicates changes in algal/ bacteria species composition and the intensity of biolipid degradation (Cranwell 1974, 1976, Kawamura and Ishiwatari 1985, Meyers 1997) or even a specific diatom input (Mudge et al. 1998). The Imboacica Lagoon samples $(0-6 \mathrm{~cm})$ reveal an averaged value of 0.72 while the two other lagoons show lower averaged values of 0.49 and 0.41 (Table III). In Imboacica Lagoon samples the more labile unsaturated fatty acid may be enhanced due to an almost exclusive origin of autochthonous algal lipids. In the other lagoons a higher proportion of short chain acids could be derived from hydrolysis of very long-chain (C44-C49) esters stemming from terrestrial plant waxes (Kolattukudy 1976). Plant waxes upon longer transportation have undergone more severe diagenetic reactions, and ester hydrolization will yield exclusively saturated acids.

The degree of unsaturation of n-C18-fatty acids (C18:1 $\omega 7 / \mathrm{C} 18: 0)$ for the $0-3 \mathrm{~cm}$ samples varies between values of 0.8 to 0.43 for the three the lagoons. This ratio reflects the intensity of bacterial input because $\mathrm{C} 18: 1 \omega 7$ is a characteristic compound in bacteria (e.g. Volkman et al. 1998, Mudge et al. 1998). Values decrease from Imboacica Lagoon over Cabiúnas Lagoon to Comprida Lagoon giving evidence for the change in bacterial contribution to the lagoon's organic matter (Table III). The occurrence of $\mathrm{C} 18: 1 \omega 9$ fatty acid in all lagoons can reflect 
several different sources: green algae, bacteria, zooplankton, or higher plants (Wakeham 1995, Mudge et al. 1998). With regards to the lipid distribution in the seaward samples, an algal or bacterial origin is obvious, but for Comprida Lagoon additional contribution from higher plants is suggested (Fig. 3c).

A parameter commonly used for the distinction between terrigenous and aqueous organic compounds is the TARFA (terrigenous/aqueous ratio of fatty acids) (Bourbonniere et al. 1991, Silliman et al. 1996, Meyers and Ishiwatari 1993). This ratio expresses the proportion of even numbered long-chain (C24-C34; in this study) to short-chain (C14-C18) saturated fatty acids. Low ratios were determined for the samples from Imboacica Lagoon: TARFA = 0.001 for the $0-3 \mathrm{~cm}$ and TARFA $=0.28$ for the depth interval 3-6 cm (Fig. 4a). This very strong predominance of short-chain fatty acids reflects the almost exclusive origin from algal precursor biomolecules, which is in agreement with: i) the sampling site position very close to the sea, ii) the enhanced nutrient availability for algae resulting from man-made eutrophication in the entire Imboacica Lagoon, and iii) the location of the sampling point close to a sewage discharge channel. High concentrations of n-C16 fatty acids were reported from a comparable setting of the Rio Formosa Lagoon, Portugal (Mudge et al. 1998).

In both lagoons still remaining under natural conditions, the molecular diversity of carboxylic acids is significantly greater, with higher values of TARFA for the surface sample $(0-3 \mathrm{~cm})$ of Cabiúnas Lagoon (0.27) and especially Comprida Lagoon (1.38) (Table III, Fig. 4a). Whereas Cabiúnas Lagoon is thus almost comparable to the setting noted for Imboacica Lagoon $(3-6 \mathrm{~cm})$ before human activity strongly altered TARFA, Comprida Lagoon is dominated by terrigenous biomass even in the seaward part. The low proportion of algal biomass is probably due to low nutrient availability and low $\mathrm{pH}$ resulting from high humic and fulvic acid concentrations. Additionally, the low overall size and size/catchment ratio for Comprida Lagoon favor terrigenous organic matter accumulation. The increas- ing values for TARFA of deeper samples can be explained either with preferential degradation and/or condensation/incorporation into polymeric organic matter of short-chain components (Meyers and Ishiwatari 1993) or with a change from limnic to more terrigenous input over time. The relatively high abundance of branched carboxylic acids with chain length $\mathrm{C} 15$ to $\mathrm{C} 19$ in the free lipids of Comprida and Cabiúnas Lagoons at samples from the seaward site indicates contribution from bacterial species different from those occurred in Imboacica Lagoon, most likely from cyanobacteria.

In comparison to Imboacica Lagoon the smaller surface to volume ratio of Cabiúnas and Comprida Lagoons will have an effect on the transport and the distribution of organic matter within the lagoons. Small size of lagoonal accumulation area in comparison to a large catchment area leads to strong terrigenous character even in the central regions. Another prominent group of bacterial biomarkers, the hopanoic carboxylic acids or alcohols could not be detected by either GC-FID or GC/MS analysis. This might be an indication of a low diversity in the bacterial community or a preferential incorporation of hopanoic acids and alcohols into macromolecular organic matter. Di-, tri- and tetracyclic diterpenoid acids (e.g. agathic acid, abietic acid, pimaric acid), common among land-derived compounds, also could not be detected.

After the carboxylic acids, n-alcohols are the next dominant class of biolipids at samples from the seaward site of the three lagoons (Fig. 3a-c), followed by sterols and n-alkanes. No short-chain homologues are observed for the n-alcohols and nalkanes in any samples from the seaward site. This absence emphasizes the predominance of terrigenous input, which clearly decreases from Comprida Lagoon to Cabiúnas Lagoon to Imboacica Lagoon (see Fig. 3a-c). The latter location is virtually free of terrigenous n-alcohols and n-alkanes. The terrestrial plant wax origin of long-chain alcohols (Kolattukudy 1976) is further indicated by a pronounced even over odd predominance for the homologous series. In the case of long-chain $n$-alkanes the plant 

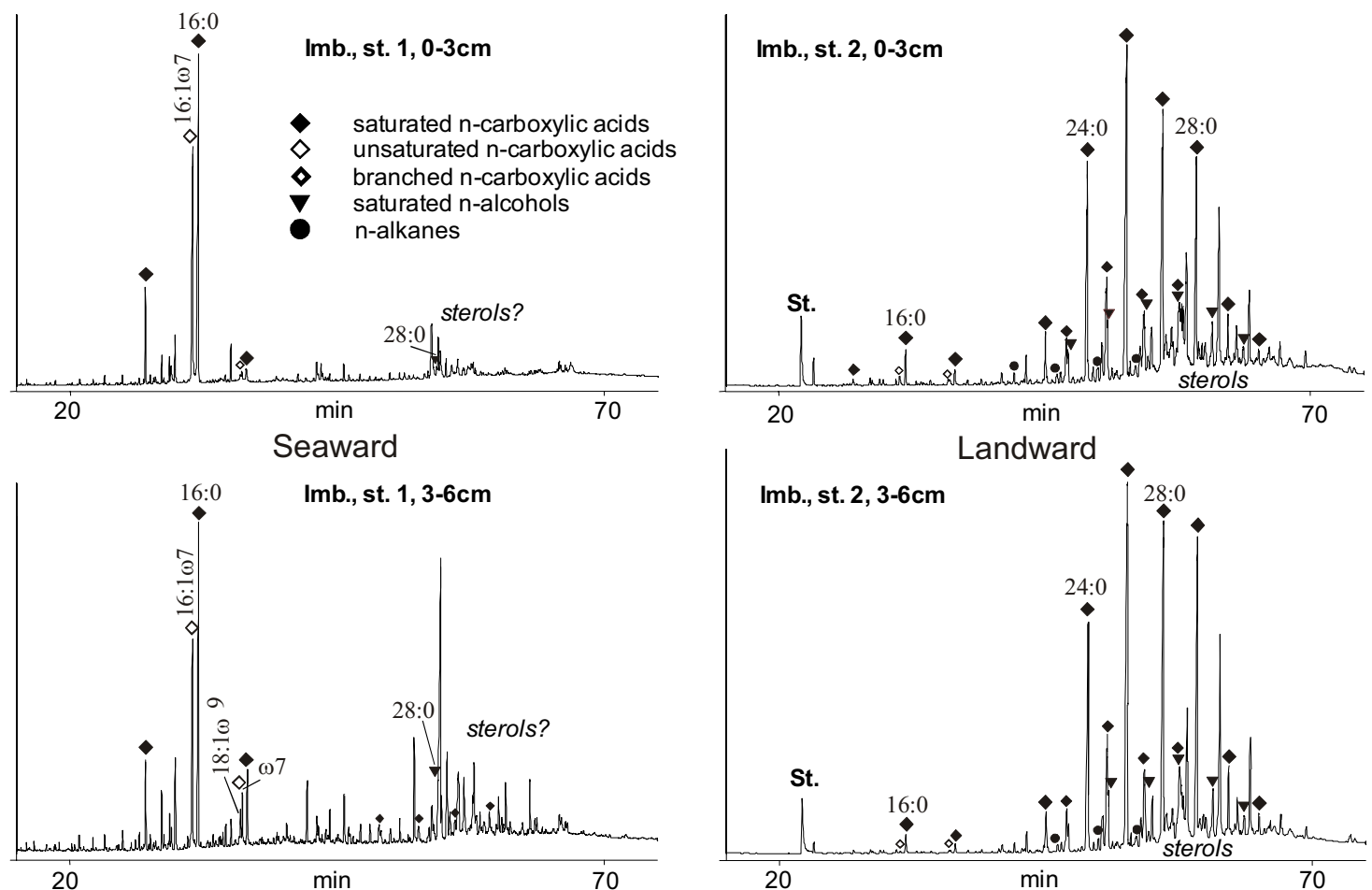

(a)
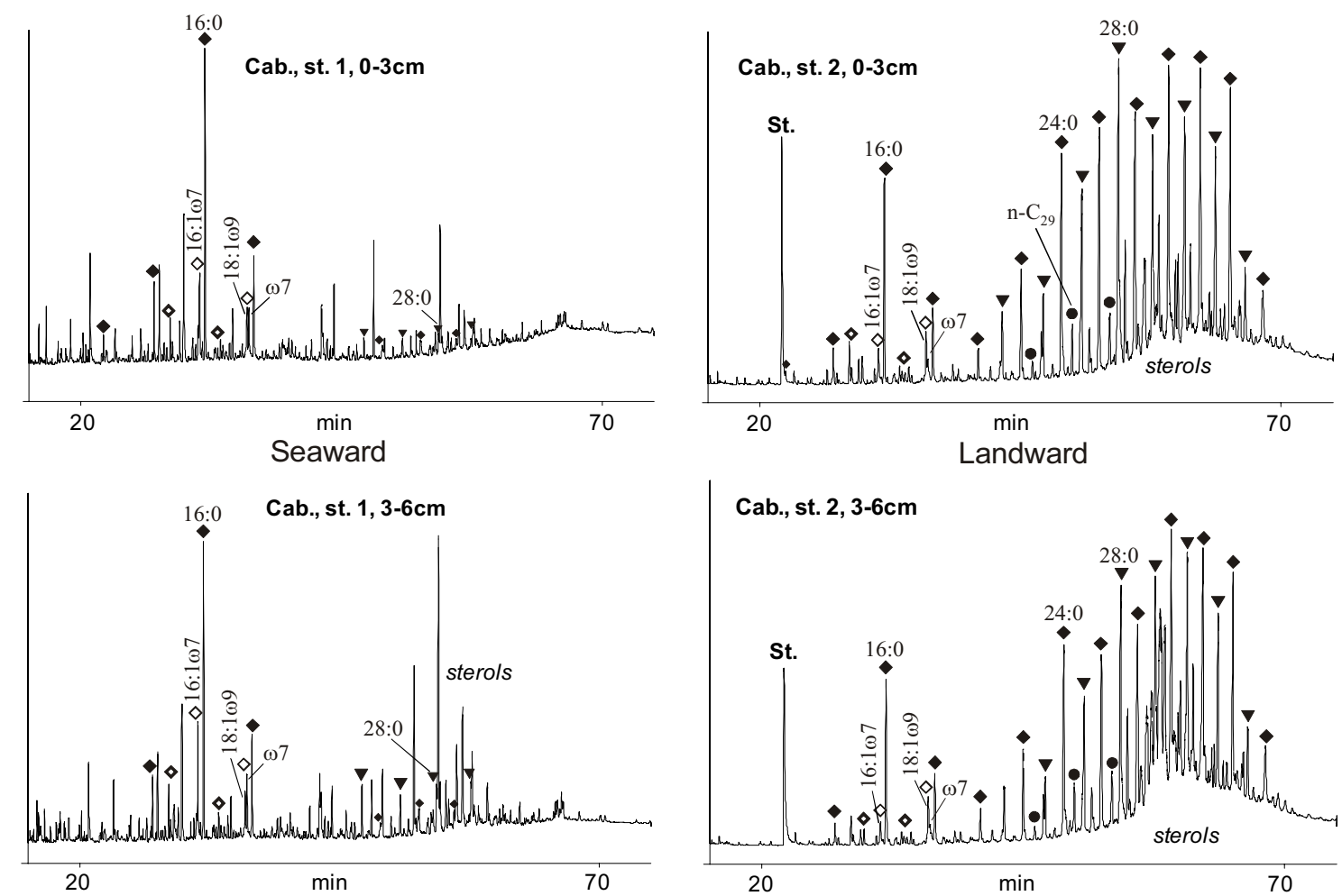

(b) 

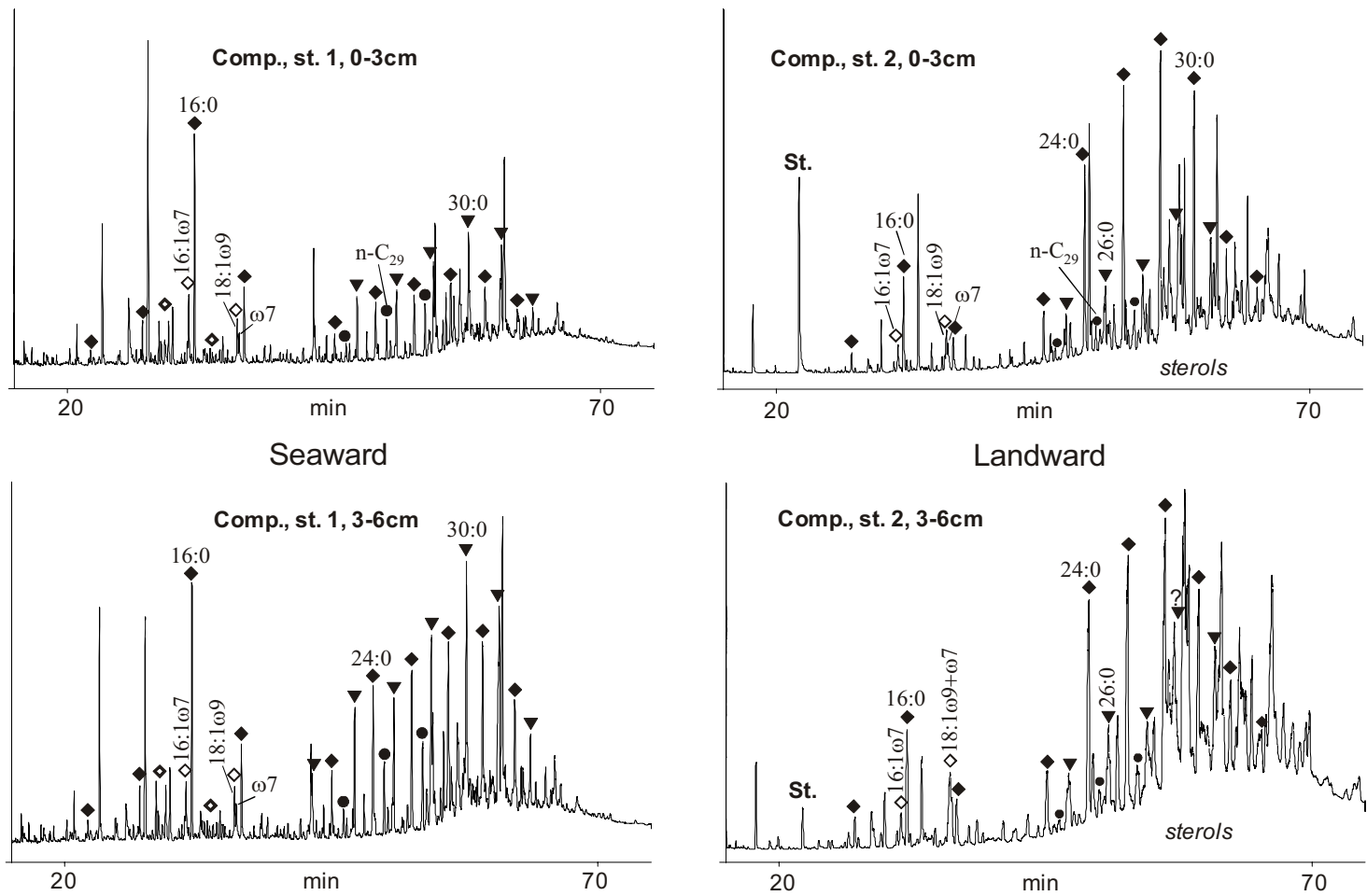

(c)

Fig. 3 - a) GC-FID trace of Imboacica Lagoon sediment total extract, derivatized with BSTFA. b) GC-FID trace of Cabiúnas Lagoon sediment total extract, derivatized with BSTFA. c) GC-FID trace of Comprida Lagoon sediment total extract, derivatized with BSTFA.

wax pattern is dominated by odd-numbered analogues (C27, C29, C31 in fig. 3a-c) (Eglinton and Hamilton 1967, Cranwell 1973, Farrimond and Flanagan 1996). This interpretation is in accordance with results obtained from bulk elemental analysis and carboxylic biomarker analyses. Sterols and a second series of unknown compounds (tentatively identified as unsaturated hydroxy-fatty acids) are present in samples from the seaward site but due to lack of mass spectrometric analyses are not discussed further.

\section{Molecular composition of lipids}

from the landward sites

The gas chromatograms obtained for samples from site 2 (landward) and site 1 (seaward) revealed striking differences in the amounts of short-chain vs. long-chain lipids (Fig. 3a-c, Fig. 4a,b). The sam- ples from all landward sites are clearly dominated by long-chain saturated carboxylic acids and alcohols reflecting a source of higher plant and aquatic macrophytes (e.g. the emergent Typha and submerged Potamogeton) in this part of the lagoons and from eroded soil material. The abundant occurrence of very long-chain fatty acids with carbon chain length up to C36 (Cabiúnas Lagoon) is nevertheless unusual and might be connected with different herbs and grasses. The partial predominance of Typha, and Potamogeton can be responsible only for the enhanced abundance of C20 and C22 fatty acids (Fig. 3b) (Cranwell 1984, Ficken et al. 2000) but probably not for the significant occurrence of C36 compounds. In addition, long-chain n-alkanes mainly with a strong odd over even predominance in $\mathrm{n}-\mathrm{C} 25$ to $\mathrm{n}-\mathrm{C} 35$ range and some sterols are present.

Short-chain carboxylic acids again have to be 
assumed to derive from algal/bacterial lipids and to a minor degree from hydrolysis of wax esters. The ratio of C16-unsaturated to saturated acids in samples from landward sites in general is lower, which can be explained by higher relative contribution of plant wax acids in relation to algal/bacterial lipids. Also the 18:1 $\omega 7 / 18: 0-F A$ ratio is lower in samples from the landward site, except for samples from Comprida Lagoon where the enhanced value for the 18:1 $\omega 7 / 18: 0-F A$ ratio of 0.84 and 1.20 might indicate additional sources than bacteria (Table III). In Comprida Lagoon the high abundance of both C18:1 $\omega$ 9- and C18:1 $\omega$ 7-fatty acids could be attributed to higher plant input (Cranwell 1982, Mudge et al. 1998), although C18:1 $\omega 9$ is also reported a prominent marker for zooplankton contribution (Wakeham 1995). The preference of the unsaturated acids is probably due to a specific plant precursor (e.g. an aquatic macrophyte). Alternatively, an origin not preferentially from epicuticular wax coatings but from intracuticular waxes or different plant constituents (essential oils, seed coatings, etc.) might be possible. The predominance of $\mathrm{C} 18: 1 \omega 9$ over C18:1 $\omega 7$ in all landward sites is concordant with this observations (Fig. 3a-c). Nevertheless, it has to be considered that $\mathrm{C} 18: 1 \omega 9$ can also originate from phytoplanktonic sources (e.g. Napolitano 1998), which agrees with their relative abundance in the seaward sites (Fig. 3b).

Extracts of Imboacica Lagoon show the most variable compound distributions. Compared to samples from the seaward site, which have almost exclusively n-C16:1 $\omega$ 7- and n-C16:0-fatty acids, extracts of Imboacica Lagoon from the landward site have the lowest concentration of short-chain acids among the three lagoons. In contrast, Cabiúnas and Comprida Lagoons still show relatively high concentrations of C16- and C18-fatty acids, although the terrigenous long-chain components dominate. Calculation of the TARFA confirms these observations with values varying from 5.7-9.0 for Cabiúnas and Comprida Lagoons to 27 and 50 for Imboacica Lagoon (Fig. 4b, Table III).

Another characteristic of Imboacica Lagoon is the very high abundance of the long-chain fatty acids compared to alcohols. The opposite is noted for Cabiúnas Lagoon with Comprida Lagoon being intermittent (Fig. 3a-c). Two possible mechanisms may account for the high acid to alcohol ratio in Imboacica Lagoon. First, oxidation of primary nalcohols will lead to the corresponding n-fatty acids. This oxidation process may be completely abiotic or microbially mediated (George and Jardine 1994). The oxidative degradation of lipids will ultimately also decrease the relative proportion of $\mathrm{C} 14$ - to $\mathrm{C} 18$ compounds, which is observed for Imboacica Lagoon samples. This stronger oxidative regime inferred from carboxylic acid distribution is in part substantiated by in situ measurements of oxygen saturation (Petrucio 1998). Another route that could potentially lead to selective accumulation of carboxylic acids may be the preferred deposition of intracuticular carboxylic acids in fine-grained Imboacica Lagoon sediments showing almost no intact plant fragments. In this sediment type, quite distinguishable from Comprida and Cabiúnas Lagoons, a higher proportion of dissolved free lipids is likely to accumulate.

Long-chain alcohols found in samples from Cabiúnas Lagoons could potentially also be attributed to freshwater algae (Volkman et al. 1999). However, such long-chain algal lipids show another distribution pattern and require almost uni-specific input from Eustigmatophyceae, not reported in Cabiúnas Lagoon (Mello and Suzuki 1998). Volkman et al. (1999) reported C22 as the main straightchain alcohol and high amounts of monounsaturated long-chain alcohols, and neither was detected in the lagoonal sediment extracts.

\section{STEROLS}

The distribution of several ubiquitous steroids can provide supporting information concerning the source of sedimentary organic matter (Huang and Meinschein 1979, Cranwell et al. 1987). The evaluation of organic matter sources to lagoonal sediments can be performed using a ternary diagram displaying relative proportion of C27, C28 and C29 

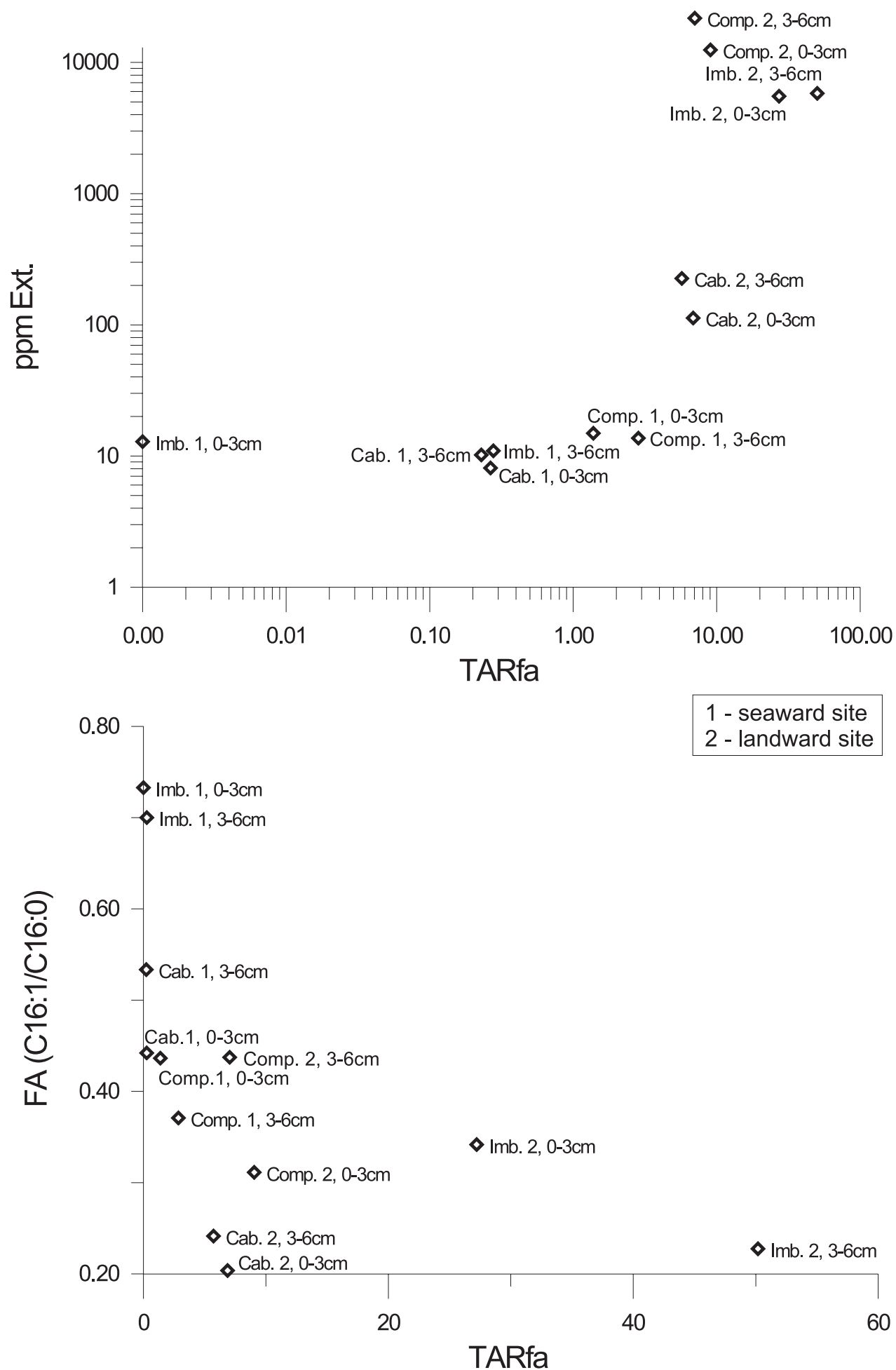

Fig. 4 - a) Crossplot of terrestrial over aquatic ratio of fatty acids [TARFA] versus extractable organic matter (ppm); b) Crossplot of terrestrial over aquatic ratio of fatty acids [TARFA] versus ratio of mono-unsaturated/saturated C16-fatty acids [FA(C16:1 $\omega$ 7/C16:0)]. 


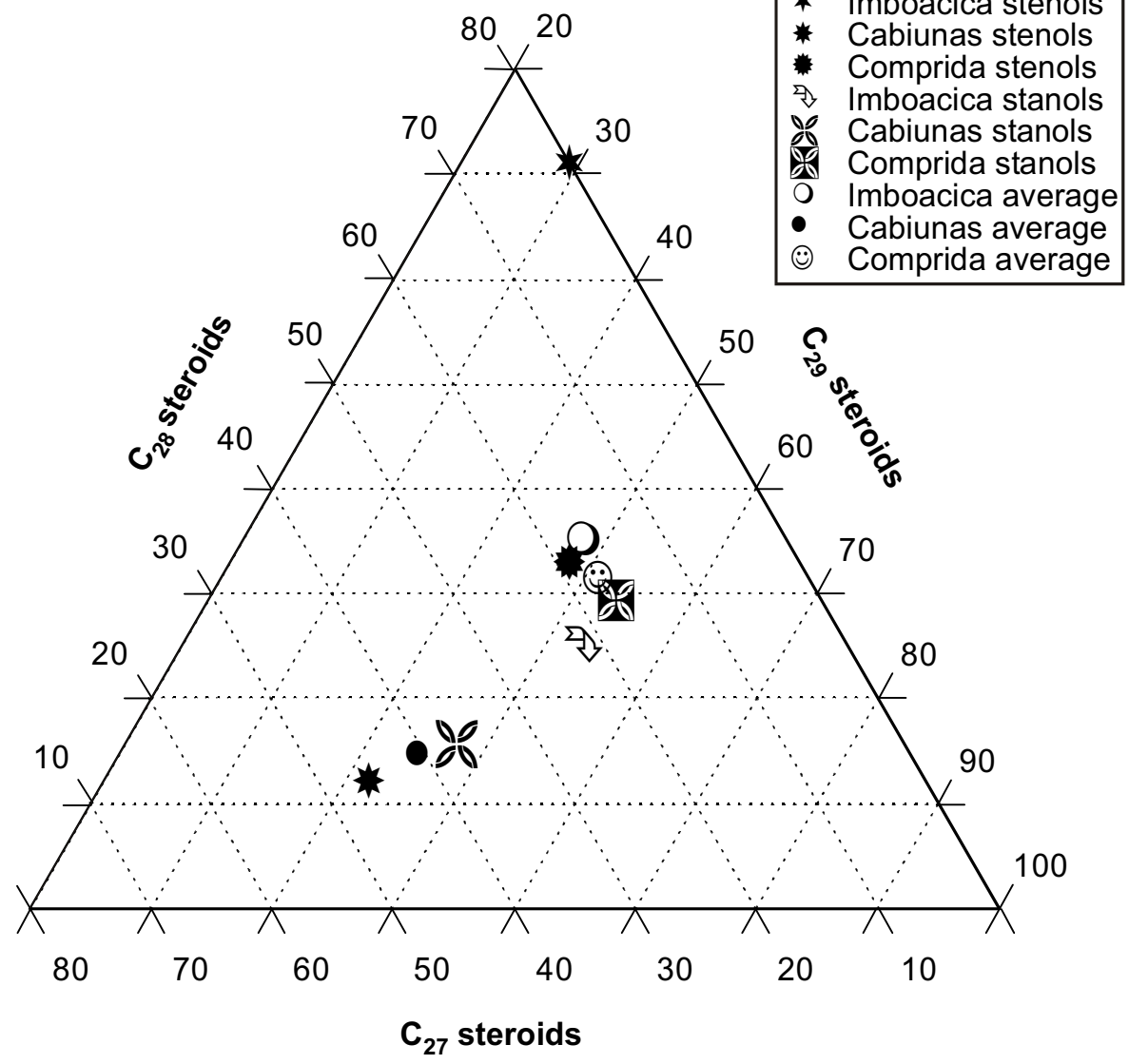

Fig. 5 - Ternary diagram showing distribution of saturated and mono-unsaturated C27 to C29 steroids.

steroids (Fig. 5). For the surficial samples from the landward site from all three lagoons, the relative proportions of mono-unsaturated $\Delta 5$ steroids cholestenol, campestenol, sitostenol and saturated counterparts cholestanol, campestanol and stigmastanol were quantified from mass fragmentograms using m/z 215 key ion (Fig. 6). As a major C29steroid stigmastenol $[24 \beta$-ethyl-cholest $(5,22)$ dien$3 \beta \mathrm{ol}$ ] occurs in significant concentrations in all samples. If this $\mathrm{C} 29$ stenol were included in the calculations, all samples would acquire an even more terrestrial source signature.

The extreme position of Imboacica Lagoon with an obvious dominance of C28 and C29 higher plant steroids and no detectable amounts of $\mathrm{C} 27$ algal steroids confirms the results obtained from $n$ carboxylic acid analysis. Cabiúnas and Comprida
Lagoons sediments are more enriched in the algal/ zooplankton derived cholestenol (C27) and therefore plot more towards the center of the ternary diagram, in an estuarine/lagoonal position. The elevated amount of $\mathrm{C} 27$ and reduced contribution of C29 steroids for samples from Cabiúnas Lagoon is in agreement with an enhanced contribution from phytoplanktonic algae as compared to samples from Comprida Lagoon. Sterol discriminant analysis places all lagoonal samples in the estuarine/lagoon/ bay field and is not particularly well suited for deduction of predominant organic matter sources.

\section{OTHER SOURCES}

The fact that no methane production was observed for any lagoon sediments (Furtado et al. 2002) is confirmed by biomarker analysis on those samples. 


\section{Cabiúnas Lagoon, st. 2, 0-3 cm: steroid occurrence}
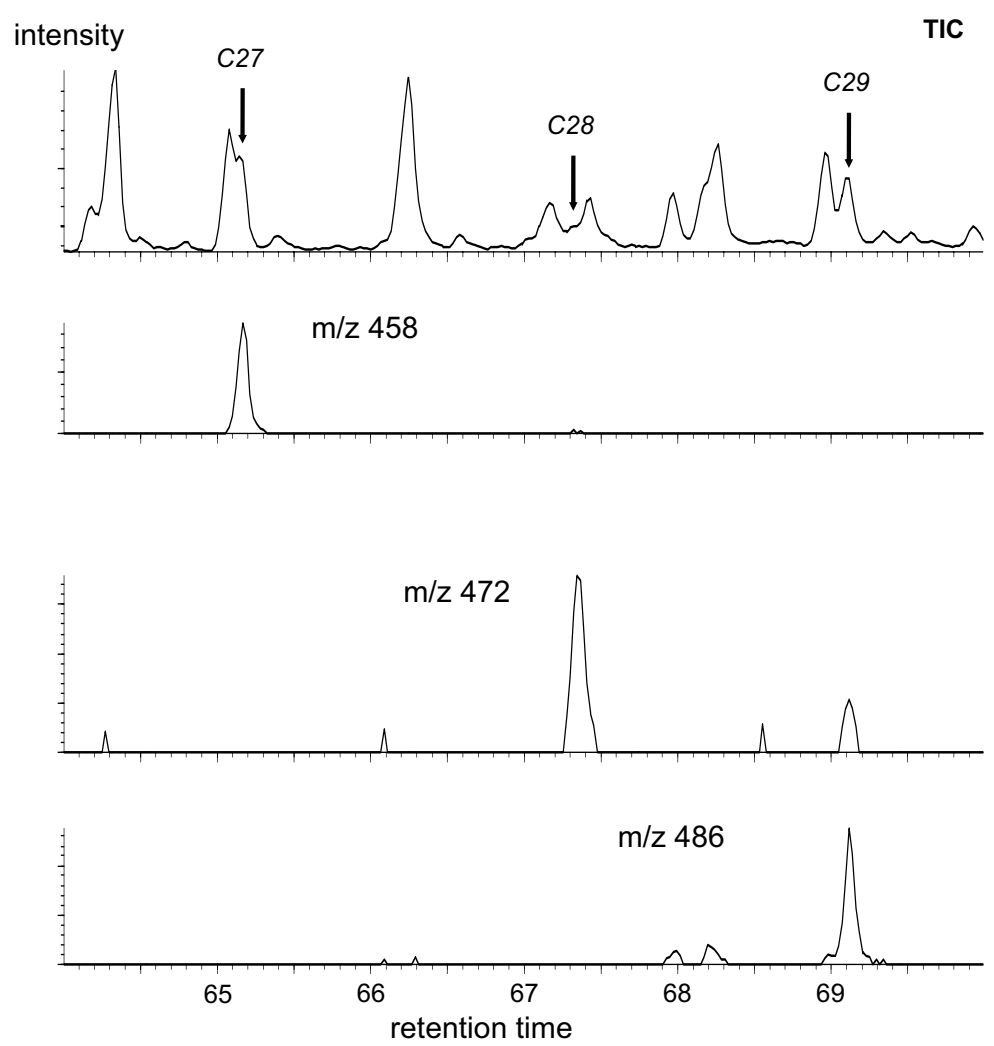

Fig. 6 - Total reconstructed ion current and selected mass fragmentograms indicating steroid distribution.

No significant amounts of biomarkers from methanogens (e.g. specific isoprenoids like pentamethylicosanes, biphytanes, squalene) or methylotrophic bacteria ( $3 \alpha$-methylhopanes) could be detected. Additionally, hopanoids, typical for bacteria and cyanophytes, are absent in all samples from the landward site as revealed by GC/MS analysis. The only indication for bacterial activity is the abundance of $\mathrm{C} 16$ and $\mathrm{C} 18$ mono-unsaturated $\omega 7$ fatty acids and higher concentrations of branched isomers of short-chain fatty acids $(\mathrm{C} 15, \mathrm{C} 16, \mathrm{C} 17)$ in samples from the seaward site. It follows that in three Brazilian lagoons studied here a special bacterial community prevails that differs from microbial assemblages common in other lakes. The relatively low abundance and productivity of pelagic bacte- ria were between 1.0 to $2.3 \times 10^{9}$ cells $/ 1$ and 1.1 to $33.7 \mu \mathrm{g} \mathrm{C} / 1$ in Cabiúnas Lagoon (Furtado et al. 2001). It remains to be confirmed by future studies if this specific bacterial association is a general feature of lagoonal environments.

Biomarkers like the fecal marker coprostanol (Nguyen et al. 1995) or PAH (polyaromatic hydrocarbons resulted from by incomplete combustion of fossil fuels) indicative for anthropogenic input into the lagoons could not be identified in significant concentrations. One reason for this absence might be fast intensive bacterial reworking of sewage material in the lagoon area where the discharge takes place, resulting in a lower fixation of anthropogenic pollution markers. 


\section{CONCLUSIONS}

Organic biomarker analysis investigation has identified sources of organic matter, evaluated its diagenetic transformation pathways and detected human disturbance in three Brazilian lagoons.

Imboacica Lagoon, located in an urbanized area, has been receiving increased anthropogenic input over recent years. This impact is preferentially archived in the topmost $3 \mathrm{~cm}$ of sediment, whereas the deeper sediment layer shows less evidence of human influence. Eutrophication is a key process controlling composition of lagoonal biological communities particularly by favoring algal (diatoms) and cyanobacterial growth. One other important process is the artificial opening of the sand barrier between lagoon and ocean that controls water chemistry and exchange of marine and lagoonal fauna. Hence, physicochemical properties like alkalinity are affected as well, as manifested in lithological change towards more carbonate precipitation in the uppermost 3 centimeters of Imboacica Lagoon sediment.

In more isolated Cabiúnas and Comprida Lagoons pristine natural ecosystems are preserved. Terrigenous organic matter dominates which is exceptionally well preserved. This is related to the physicochemical properties of lagoonal waters, in particular their high acidity. Differentiation between landward and seaward sites in these lagoons is less pronounced because of much smaller surface/volume to catchment ratios. No anthropogenic influences are yet detectable in sediments of Cabiúnas and Comprida Lagoons.

\section{ACKNOWLEDGMENTS}

Technical assistance by B. Stapper and R. Lösing is gratefully acknowledged. We thank the Oekumenisches Studentenwerk e.V. for the financial support, which enabled the sampling in the lagoons, and Prof. Dr. Francisco de Assis Esteves for logistic support in Brazil.

\section{RESUMO}

As lagoas costeiras são importantes ecossistemas costeiros no Estado do Rio de Janeiro, localizadas entre áreas urbanizadas da costa e o oceano aberto. Vários estudos enfocando o sedimento, a água, a comunidade zooplanctônica e comunidades bacterianas demonstraram a extensão da influência antrópica sobre estes ecossistemas aquáticos. Neste estudo foi investigada a composição da matéria orgânica presente no sedimento, assim como, alguns parâmetros microbiológicos, com o intuito de caracterizar três lagoas costeiras. Matéria orgânica e lipídeos (hidrocarbonetos alifáticos, álcoois e ácidos graxos, esteróis) foram analisados em dois pontos de amostragem em cada lagoa (região continental e região marinha), em dois intervalos da profundidade $(0-3$ e $3-6 \mathrm{~cm})$. A lagoa Imboacica apresentou maior influência antrópica nos últimos anos, representada na fração superficial do sedimento $(0-3 \mathrm{~cm})$, visto que na camada mais profunda (3-6 cm) observou-se reduzida influência humana. A eutrofização da lagoa ou disponibilidade de nutrientes favoreceram o crescimento acentuado de algas e cianobactérias. Nas lagoas Cabiúnas e Comprida, afastadas do perímetro urbano, as características naturais mostraram-se preservadas. A matéria orgânica oriunda de plantas vasculares é dominante, apresentando-se excepcionalmente bem preservada em função das características ácidas da água. A discreta diferenciação entre a região continental e a marinha, nestas duas lagoas, está diretamente relacionada à reduzida razão superfície/volume destes ecossistemas aquáticos. Nenhuma influência antropogênica foi observada no sedimento das lagoas Cabiúnas e Comprida.

Palavras-chave: lagoas costeiras, produção aquática/terrestre, lipídios, ácidos graxos, esteróis, Brasil.

\section{REFERENCES}

Aмвül H AND BüHRER H. 1975. Zur Technik der Entnahme ungestörter Großproben von Seesedimenten: ein verbessertes Bohrlot. Schweiz Z Hydrol 37: 175186.

Araújo DSD and Henriques RP. 1984. Análise florística das restingas do Estado do Rio de Janeiro. In: LACERDA LD ET AL. (Ed.), Restingas: origem, estrutura e processos, Niterói: CEUFF, p. 159-193. 
Bertone S, Giacomini M, Ruggiero C, Piccarolo C And Calegari L. 1996. Automated systems for identification of heterotrophic marine bacteria on the basis of their fatty acid composition. Appl Environ Microbiol 62: 2122-2132.

Biesboer DD, Esteves FA And Enrich-Prast A. 1998. Nitrogen fixation and denitrification in Lagoa Imboassica, a coastal lagoon of Rio de Janeiro State, Brazil. Verh Int Ver Theoret Angew Limnol 26: 1412-1417.

Bourbonniere RA, Meyers PA, Eadie BJ, Robbins JA. 1991. Environmental and diagenetic effects on geolipid compositions of sediments in Lakes Erie and Ontario. In: Manning D (Ed.), Advances and Applications in Energy and the Natural Environment, p. 498-501.

Budge SM AND PARRISH CC. 1998. Lipid biogeochemistry of plankton, settling latter and sediments in Trinity Bay, Newfoundland. II. Fatty acids. Org Geochem 29: 1547-1559.

Cranwell PA. 1973. Chain-length distribution of nalkanes from lake sediments in relation to post-glacial environmental change. Freshwat Biol 3: 259-265.

Cranwell PA. 1974. Monocarboxylic acids in lake sediments. Indicators, derived from terrestrial and aquatic biota, of paleoenvironmental trophic levels. Chem Geol 14: 1-14.

Cranwell PA. 1976. Organic compounds as indicators of allochthonous and autochthonous input to lake sediments. In: Golterman HL (Ed.), Interactions between Sediments and Fresh Water, Junk, The Hague, p. 133-141.

Cranwell PA. 1982. Lipids of aquatic sediments and sedimenting particulates. Prog Lipid Res 21: 271-308.

Cranwell PA. 1984. Lipid geochemistry of sediments from Upton Broad, a small productive lake. Org Geochem 7: 25-37.

Cranwell PA, Eglinton G and Robinson N. 1987. Lipids of aquatic organisms as potential contributors to lacustrine sediments - II. Org Geochem 11: 513-527.

EgLinton G And Hamilton RJ. 1967. Leaf epicuticular waxes. Science 156: 1322-1335.

FARRIMOND P AND FLANAGAN RL. 1996. Lipid stratigraphy of a Flandrian peat bed (Northumberland,
UK): comparison with the pollen record. Holocene 6: 69-74.

Ficken KJ, Li B, Swain DL and Eglinton G. 2000. An $n$-alkane proxy for the sedimentary input of submerged/floating freshwater aquatic macrophytes. Org Geochem 31: 745-749.

FIDERJ. 1977. Estudos para o planejamento municipal. Rio de Janeiro: Macaé, 76 p.

Furtado ALS And Esteves FA. 1997. Biological nitrogen fixation in a brazilian coastal lagoon. Arq Biol Tecnol 40: 143-151.

Furtado ALS, Petrucio MM and Esteves FA. 1997. $\mathrm{C}, \mathrm{N}, \mathrm{P}$ and pheopigments in the sediment of a brazilian coastal lagoon, Macaé, Rio de Janeiro. Rev Bras Biol 57: 127-134.

Furtado ALS, Casper P And Esteves FA. 2001. Bacterioplankton abundance, biomass and production in a Brazilian coastal lagoon and in two German lakes. An Acad Bras Cienc 73: 39-49.

Furtado ALS, Casper P and Esteves FA. 2002. Methanogenesis in an impacted and two dystrophic coastal lagoons (Macaé, Brazil). Braz Arch Biol technol 45: 195-202.

Gelpi E, Schneider H, Mann J and Oró J. 1970. Hydrocarbons of geochemical significance in microscopic algae. Phytochemistry 9: 603-612.

George SC ANd Jardine DR. 1994. Ketones in a Proterozoic dolerite sill. Org Geochem 21: 829-839.

Gonçalves JF, Callisto M and Leal JJF. 1998. Relação entre a composição granulométrica do sedimento e as comunidades de macroinvertebrados bentônicos nas lagoas Imboassica, Cabiúnas e Comprida. In: Esteves FA (Ed.), Ecologia das Lagoas Costeiras do Parque Nacional da Restinga de Jurubatiba e do Município de Macaé, Rio de Janeiro: NUPEM/UFRJ, p. 299-310.

Han J AND Calvin M. 1969. Hydrocarbon distribution of algae and bacteria and microbiological activity in sediments. Proc Natl Acad Sci USA 64: 436-443.

Hinrichs K-U, Summons RE, Orphan V, Sylva SP AND HAYES JM. 2000. Molecular and isotopic analysis of anaerobic methane-oxidizing communities in marine sediments. Org Geochem 31: 1685-1701.

Huang W-Y and Meinschein WG. 1979. Sterols as ecological indicators. Geochim Cosmochim Acta 43: 739-745. 
KAWAMUra K AND Ishiwatari R. 1981. Polyunsaturated fatty acids in a lacustrine sediment as a possible indicator of paleoclimate. Geochim Cosmochim Acta 45: 149-155.

KAWAMURA K AND IshiwataRI R. 1985. Distribution of lipid-class compounds in bottom sediments of freshwater lakes with different trophic status in Japan. Chem Geol 51: 123-133.

Kolattukudy PE (Ed.). 1976. Chemistry and Biochemistry of Natural Waxes. Amsterdam: Elsevier. p. 460.

Kozlowsky-Suzuki B, Branco CWC and Bozelli RL. 1998. Comparison of the composition and the temporal variation of the zooplanktonic community of two Brazilian coastal lagoons. Verh Int Ver Theoret Angew Limnol 26: 1487-1490.

LOPEZ-FERREIRA CM. 1998. Redução das concentrações de nitrogênio e fósforo dos efluentes domésticos lançados na lagoa Imboacica, através de uma região colonizada por macrófitas aquáticas. In: Esteves FA (Ed.), Ecologia das Lagoas Costeiras do Parque Nacional da Restinga de Jurubatiba e do Município de Macaé, Rio de Janeiro: NUPEM/UFRJ, p. 375-398.

Lutz R, Gieren B, LüCKGe A, Wilkes H And Littke R. 2000. Composition of organic matter in subducted and unsubducted sediments off the Nicoya peninsula, Costa Rica (ODP Leg 170, Sites 1039 and 1040). Org Geochem 31: 1597-1610.

Mello S AND SuzuKi MS. 1998. Variações temporais e espaciais do fitoplâncton das lagoas Imboassica, Cabiúnas e Comprida. In: Esteves FA (Ed.), Ecologia das Lagoas Costeiras do Parque Nacional da Restinga de Jurubatiba e do Município de Macaé, Rio de Janeiro: NUPEM/UFRJ, p. 178-203.

Meyers PA. 1997. Organic geochemical proxies of paleoceanographic, paleolimnologic, and paleoclimate processes. Org Geochem 27: 213-250.

MEYers PA AND IshiWATARI R. 1993. Lacustrine organic geochemistry - an overview of indicators of organic matter sources and diagenesis in lake sediments. Org Geochem 20: 867-900.

Mudge SM, East JA, Bebianno MJ and Barreira LA. 1998. Fatty acids in the Ria Formosa Lagoon, Portugal. Org Geochem 29: 963-977.

Napolitano GE. 1998. Fatty acids as trophic and chemical markers in freshwater ecosystems. In: ARTs
MT AND WaInMAn BC (Eds.), Lipids in Freshwater Ecosystems, p. 21-44.

Nguyen D-K, Bruchet A and Arpino P. 1995. Determination of sterols in sewage sludge by combined in situ trimethylsilylation/supercritical fluid extraction and GC/MS. Environ Sci Technol 29: 1686-1690.

Panosso RF, Attayde JL and Muehe D. 1998. Morfometria das Lagoas Imboassica, Cabiúnas, Comprida e Carapebus: Implicações para seu funcionamento e manejo. In: Esteves FA (Ed.), Ecologia das Lagoas Costeiras do Parque Nacional da Restinga de Jurubatiba e do Município de Macaé, Rio de Janeiro: NUPEM/UFRJ, p. 91-108.

Pedrosa P, Calasans CVC and Rezende CE. 1999. Particulate and dissolved phases as indicators of limnological and ecophysiological spatial variation in Cima Lake system, Brazil: a case study. Hydrobiologia 411: 89-101.

Perrin P. 1984. Evolução da costa fluminense entre as Pontas de Itacoatiara e Negra: preenchimentos e restingas. In: LACERDA LD ET AL. (Eds.), Restingas: origem, estrutura e processos, Niterói: CEUFF, p. 65-74.

Petrucio MM. 1998. Caracterização das Lagoas Imboassica, Cabiúnas, Comprida e Carapebus a partir da temperatura, salinidade, condutividade, alcalinidade, $\mathrm{O}_{2}$ dissolvido, $\mathrm{pH}$, transparência e material em suspensão. In: Esteves FA (Ed.), Ecologia das Lagoas Costeiras do Parque Nacional da Restinga de Jurubatiba e do Município de Macaé, Rio de Janeiro: NUPEM/UFRJ, p. 109-122.

Qualls RG AND Haines BL. 1990. The influence of humic substances on the aerobic decomposition of submerged leaf litter. Hydrobiologia 206: 133-138.

Santos EG, Branco CWC and Xavier-DA-Silva J. 1998. Evaluation of environmetal conditions in a Brazilian coastal lagoon (Lagoa Imboacica, R.J.) and surrounding area using geoprocessing. Verh Int Ver Theoret Angew Limnol 26: 1499-1502.

Silliman JE, Meyers PA and Bourbonniere RA. 1996. Record of postglacial organic matter delivery and burial in sediments of Lake Ontario. Org Geochem 24: 463-472.

Tyson RV. 1995. Sedimentary organic matter: Organic Facies and Palynofacies, London: Chapman \& Hall, p. 615 . 
VolKman JK. 1986. A review of sterol markers for marine and terrigenous organic matter. Org Geochem 9: 83-99.

Volkman JK, JefFrey SW, Nichols PD, Rogers GI AND GARLAND CD. 1989. Fatty acid and lipid composition of 10 species of microalgae used in mariculture. J Exp Mar Biol Ecol 128: 219-240.

Volkman JK, Barrett SM, Blackburn SI, Mansour MP, Sikes EL And Gelin F. 1998. Microalgal biomarkers: A review of recent research developments. Org Geochem 29: 1163-1179.
Volkman JK, Barrett SM AND BlackbURn SI. 1999. Eustigmatophyte microalgae are potential sources of C29 sterols, C22-C28 n-alcohols and C28-C32nalkyl diols in freshwater environments. Org Geochem 30: 307-318.

WAKEHAM SG. 1995. Lipid biomarkers for heterotrophic alteration of suspended particulate organic matter in oxygenated and anoxic water columns of the ocean. Deep-Sea Res (Part I) 42: 1749-1771.

Windom HL, Niencheski LF and Smith RG JR. 1999. Biogeochemistry of nutrients and trace metals in the estuarine region of Patos lagoon (Brazil). Est Coast Shelf Sci 48: 113-123. 